RERTATIE MIE MALLED

Campinas-SP, v.41, n.2, pp. 449-466, jul./dez. 2021

\title{
HISTORIA MAGISTRA VITAE E SUA (Des)Continuidade em Pinheiro Chagas
}

\author{
HISTORIA MAGISTRA VITAE AND ITS \\ (Dis)Continuity in Pinheiro Chagas
}

\author{
Cleber Vinicius do Amaral Felipe ${ }^{1}$
}

\begin{abstract}
Resumo: O topos historia magistra vitae, sistematizado por Cícero para afirmar o caráter exemplar e moral da história, foi apropriado por cronistas, historiadores e romancistas portugueses ao longo dos séculos XV-XIX. No Oitocentos, em particular, lugares-comuns recorrentes antigos e modernos foram associados a artifícios românticos (expressivos, psicológicos, científicos, patrióticos etc.) e circularam sobejamente nas letras portuguesas. O antagonismo entre historiadores e literatos não deve ofuscar as tópicas compartilhadas, os diálogos travados e os projetos comuns, especialmente aqueles com apelo nacional. Pretende-se avaliar de que maneira a historiografia portuguesa do século XIX retomou preceitos outrora constituintes e definidores da historia magistra vitae, conferindo especial atenção aos escritos de Pinheiro Chagas. Por meio desse trabalho, notamos dois movimentos simultâneos em se tratando da historiografia portuguesa oitocentista: a perseverança de aspectos epistêmicos, normativos e pedagógicos, outrora reunidos na concepção de história exemplar, e a descontinuidade do topos, tão perceptível quanto maior for nosso interesse em historicizar o passado.
\end{abstract}

Palavras-chave: historia magistra vitae; retórica; Pinheiro Chagas.

Abstract: The topos historia magistra vitae, systematized by Cicero to affirm the exemplary and moral character of history, was appropriated by Portuguese chroniclers and historians throughout the 15th-19th centuries. In the 19th century, commonplaces from exemplary history, associated with romantic devices (expressive, psychological, scientific, nationalistic, patriotic, etc.) and circulated abundantly in Portuguese letters. The antagonism between historians and novelists should not overshadow shared topics, dialogues and common projects, especially those with national appeal. The antagonism

${ }^{1}$ Professor do Instituto de História da Universidade Federal de Uberlândia (INHIS-UFU): <cleber.ufu@gmail.com>. 
between historians and scholars should not overshadow shared topics, dialogues and common projects, especially those with national appeal. It is intended to evaluate how the Portuguese historiography of the nineteenth century took up precepts that once constituted and defined the historia magistra vitae, paying special attention to the writings of Pinheiro Chagas. Through this work, we noticed two simultaneous movements when it comes to 19th century Portuguese historiography: the perseverance of epistemic, normative and pedagogical aspects formerly brought together in the conception of exemplary history and the discontinuity of the topos, as noticeable the greater our interest in historicizing the past.

Keywords: historia magistra vitae; Rhetoric; Pinheiro Chagas.

Christopher Bouton (2018) escreveu um artigo voltado para as transformações do topos historia magistra vitae na Modernidade. Seu objetivo foi levantar algumas objeções à hipótese de Reinhart Koselleck, publicada em 1967, sobre a dissolução [auflösung] da história exemplar de matriz ciceroniana, ocorrida após a Revolução Francesa. Detendo-se sobretudo nas reflexões de Droysen e Nietzsche, Bouton afirmou que a concepção prática ou pragmática da história se transformou, especialmente quando suas diferentes funções (epistêmica, normativa, pedagógica e pragmática) foram fragmentadas e pensadas separadamente. Nesse caso, não teria desaparecido, por exemplo, a valorização das grandes ações pretéritas, muito embora essa busca fosse realizada com o intuito de legitimar mudanças ou ações sem precedentes, inaugurais. A valorização do passado, naquele momento, teria conduzido à crescente consciência da sua historicidade, isto é, as ações de outrora, circunscritas a um contexto particular, dificultam a extração de princípios gerais frente à singularidade de cada época ou experiência.

Quando Koselleck (2006) tratou da dissolução da historia magistra vitae no século XVIII e do surgimento das filosofias da história, localizando, nesse momento, uma nova relação entre campo de experiência e horizonte de expectativa, não propôs o fim do topos, mas a fragmentação, o deslocamento e uma apropriação histórica de seus predicados. Sua análise, circunscrita a um recorte espaçotemporal particular, não pode abranger acriticamente outras culturas sem sacrificar suas especificidades históricas. É o caso, por exemplo, do Brasil oitocentista, no qual oradores como Cícero e Plutarco continuaram sendo evocados/emulados para reforçar o caráter exemplar da história ou da biografia. Entretanto, a presença de auctores antigos não indica propriamente a manutenção plena de seus arrazoados, mas a produção de um novo arranjo, que abrange também o imperativo da nacionalidade e as prerrogativas da recente historiografia científica. 
Temístocles Cezar (2019) e Valdei Araújo (2011) estudaram a presença da tópica em questão no Brasil do século XIX. É preciso considerar que a nação e a história nacional brasileira foram construídas simultaneamente, ou seja, a identidade do brasileiro e o éthos do historiador eram objetos de reflexão naquele momento. O Instituto Histórico e Geográfico Brasileiro (IHGB), criado em 1838, buscou regular e, portanto, elaborar os preceitos que deveriam conduzir a escrita da história. De acordo com Temístocles Cezar (2019, pp. 26-27), o IHGB acabaria encarnando a figura do herói ao propor a construção da memória nacional e, também, os modelos heroicos que a tornaram possível. As biografias, no caso, assumiriam uma posição de destaque ao edificar, pelo registro individual, um modelo de comportamento a ser emulado. Haveria, portanto, uma "retórica da história” a serviço da nação, capaz de conferir-lhe visibilidade e despertar o patriotismo de seu povo.

Valdei Araújo (2011), ao refletir sobre a relação entre ciência e moral na produção historiográfica brasileira do mesmo período, afirmou que os fragmentos provenientes do "estreitamento" do topos ciceroniano foram combinados em âmbito nacional, regional e individual e mesclados com elementos modernos. Nesse século XIX, além da especialização da história, haveria a proposição de uma educação sentimental e/ou moral voltada para os integrantes da nação, frequentemente figurada nos romances históricos. Foi nessas condições que o gênero vita foi apropriado para representar os heróis nacionais e suas particularidades. Dito de outra forma, os panegíricos não mais se baseariam necessariamente em tópicas buscadas em manuais de retórica, mas nas expectativas ético-políticas características de uma nação em formação. Sendo assim, podemos falar de "(in)definição" do topos, como fez Temístocles Cezar (2019), ou do "estreitamento", como preferiu Araújo (2011), para chegar à conclusão de que tópicas historiográficas da antiguidade continuaram circulando e foram incorporadas em projetos nacionais, assim como elementos mais recentes, advindos de reflexões modernas afeitas à filosofia da história, com suas exigências e particularidades.

Na revista do IHGB havia uma seção dedicada à vida de brasileiros ilustres. Os textos publicados, segundo Maria da Glória de Oliveira (2015), apresentavam dois aspectos imbricados: um, de caráter político, dizia respeito à construção de uma "retórica da nacionalidade" capaz de reforçar a origem e a identidade compartilhada pelos brasileiros; o outro, de ordem epistemológica, relacionava-se ao processo de institucionalização 
da pesquisa e da escrita histórica. Logo, nota-se um ajuste entre o caráter exemplar dessa reunião de brasileiros ilustres e a modernização da historiografia, relacionada ao surgimento das filosofias da história e, portanto, à busca pelo sentido histórico. Haveria, então, de um lado, o indivíduo exemplar, transformado em modelo de comportamento, e, de outro, o sujeito coletivo, que acompanha a marcha da razão e o "movimento geral" da história.

Chartier (2011) lembra-nos que, para os antigos, não havia separação entre "história como narrativa" e "história como passado". Hayden White (2001) também assegura que, até o final do século XVIII, a história era um ramo da retórica e, portanto, uma arte (ars, téchne). As histórias não se pautavam nas tópicas do progresso e do evolucionismo, mas na tradição, na imitação dos antigos, na referencialidade do campo de experiências. Na condição de gênero fundamentado no magistério, essa história durou, com variações em seus usos, por dois milênios e teve seu valor reconhecido em território lusitano, ainda que para eleger modelos de comportamento que estavam sendo produzidos no presente ou que deveriam perseverar no porvir.

Parece-nos que há uma descontinuidade do topos historia magistra vitae quando se leva em consideração a produção historiográfica e ficcional portuguesa entre os séculos XVIII eXIX. O presente artigo, para perscrutar essa hipótese, desdobra-se em dois momentos: o primeiro concentra-se, brevemente, na concepção providencialista da história no contexto contrarreformado; o segundo, tomando como base escritos de Alexandre Herculano, Oliveira Martins e, sobretudo, de Manuel Pinheiro Chagas, analisa vestígios do topos, recorrentemente tomados como descrições empíricas ou como fruto de relato testemunhal. Constata-se, assim, que o artifício foi interpretado como expressão natural, o que demonstra sua eficácia no século XIX.

\section{A HISTÓRIA EXEMPLAR NO OITOCENTOS PORTUGUÊS}

Aconcepção de história mestra da vida pode ser facilmente encontrada no XVII português, quando muitos historiadores recorreram a manuais e tratados espanhóis, italianos e franceses para escrever e legitimar a história lusitana durante o processo de Restauração (MEGIANI; CERQUEIRA, 2020). O topos perseverou no século seguinte, como é possível notar em uma das censuras à obra de Telles da Silva (1727, [s.p.]), no seguinte trecho: 
Se qualquer História é testemunha do tempo, luz da verdade, vida da memória, mestra da vida, e mensageira da antiguidade, que será da História de Portugal? Será testemunha do merecimento, luz da erudição, vida do entendimento, mestra da heroicidade, mensageira da glória imortal?

\section{No excerto, o censor}

[...] emulou a tópica ciceroniana atribuindo-lhe novo formato, desta vez matizando as prioridades da própria Academia. No entanto, este novo formato não refuta ou contraria o antigo: alude-se ao mérito dos portugueses, à erudição e entendimento daqueles que escrevem história, à heroicidade das ações e à fama decorrente delas. Faz-se, portanto, um exercício de "particularização" da tópica em conformidade com os protocolos da Academia, que continua com o objetivo de propor a exemplaridade da história portuguesa em suas dimensões eclesiástica e secular. O censor afirmou que a história então narrada não perderia em nada perante as histórias antigas, muitas vezes conseguindo superá-la no que se refere não apenas aos exemplos elencados, mas também à escrita empregada (FELIPE, 2015, pp. 57-58).

Os modelos da história seiscentista e setecentista remontam, como afirma Eduardo Sinkevisque (2013, p. 47), à "chamada Idade Média e à Antiguidade greco-romana”. O gênero, portanto, deve ser lido

[...] por meio da Poética e da Retórica aristotélicas e da Arte Poética de Horácio, pois o discurso se faz in ordo naturalis, com elocução na primeira pessoa testemunhal, de um narrador não autor das matérias, mas ponderador, que discorre ou faz arrazoados e juízos a respeito das ações sucedidas a particulares (SINKEVISQUE, 2013, p. 47).

Para referir a história do século XVII, Sinkevisque utiliza a expressão “prosa imitativo-emuladora”. Assim, ele reforça sua condição retórica e prescritiva, pois foi inventada, disposta e ornamentada em conformidade com prescrições genéricas longevas que continuavam em voga no século XVIII e que foram desconstruídas pelas então emergentes filosofias da história.

Gregos e romanos não conheceram a concepção providencialista de história como os portugueses, ou seja, ignoravam a "Identidade de Deus, Causa Primeira, [que] repete-se em todas as diferenças históricas do tempo, tornando análogos ou semelhantes todos os seus momentos, desde a Criação até o presente dos intérpretes" (HANSEN, 2006, p. 58). Com a ontologia cristã, dois planos passaram a ser concebidos ao mesmo tempo: um mundo sensível e contingente, e outro radicalmente distinto, transcendente. O pensamento, nesse caso, assume a forma de categorias duais e irreconciliáveis: material/espiritual, sagrado/profano, temporal/ 
eterno etc. A divindade, por não se encontrar sujeita à causalidade, precisou ser alocada em outro plano (KOSELLECK, 2006).

Para entender a maneira como os portugueses dos séculos XVI-XVIII compreendiam a história, é imprescindível, assim, considerar a harmonia existente entre a "razão política" e a "ética cristã", reforçada pela metáfora do corpo místico. No caso, pressupõe-se a relevância de uma hierarquia articulada com rigidez, por se tratar de um reflexo da lei natural. O Império português contaria com a regência do rei, cabeça da hierarquia política e, portanto, o responsável pela condução sadia de seu reino. Aos súditos, integrantes do corpo político, restaria o respeito incondicional, fator que proporcionaria o bem-comum. A subordinação, nesse caso, equivalia ao bom uso do livre-arbítrio, e o respeito aos superiores tornar-se-ia legítimo, porque análogo à situação cristã, marcada pela submissão do corpo de fiéis aos dogmas da Igreja Católica, encabeçada por Cristo (KANTOROWICZ, 1998, pp. 132-137).

Ao longo do Oitocentos, uma das manifestações da historia magistra vitae se deu por intermédio do chamado "romance histórico", gênero plural comumente caracterizado pelo uso ficcional de informações históricas ou pelo encontro entre elementos retirados dos manuais da área e o emprego da imaginação, de modo que o romancista seria um intermediário entre a documentação consultada e o público leitor.

Em seus Ensaios críticos, Pinheiro Chagas (1866, p. 58) escreveu que a missão do romancista histórico era "mais grandiosa, mais sublime do que a do próprio historiador". Ambos consultam as histórias e delas "arrancam os espectros das gerações extintas do seu túmulo secular" (p. 58). O historiador, no entanto, "estende o cadáver na mesa anatômica" e se contenta em "explicar friamente" os mistérios do organismo e investigar "o modo como o fluido vital fazia jogar essas molas, que a morte despedaçou, e cujos segredos o tempo obliterara" (p. 58). O romancista, por outro lado, "galvaniza o cadáver, restitui-lhe o movimento" de modo que o leitor "vê passar por diante de si não o esqueleto hirto e gélido, mas o corpo animado com o calor da vida, com o fogo das paixões, que o animara, que o abrasara outrora" (CHAGAS, 1866, p. 58).

Jules Michelet (2010) afirmou que o historiador deveria avançar, adentrar-se, mergulhar, visitar os porões eos túmulos eas galerias solitárias dos arquivos. Nos documentos, a verdade não se apresentaria aos olhos de imediato e, por isso, o historiador "é não só um mergulhador, visitante dos mortos e dos arquivos, o viajante com olhar-participante, mas ainda 
deve ser dotado de ouvido porque a história fala" (HARTOG, 2011, pp. 154-155), ou seja, os arquivos não estão completamente mortos, e suas vozes podem ser ouvidas por meio da documentação. O historiador, portanto, não apenas deixa falar, mas formula o que os agentes responsáveis pela documentação não puderam - ou não souberam - formular. "O indizível de outrora é algo do não dito que, um dia, deve ser dito: pelo historiador" (p. 155). O conhecimento do historiador ultrapassa aquilo que sabiam os mortos e, por isso mesmo, ele seria capaz de escutar palavras que não foram pronunciadas. No prefácio de 1868 à História da Revolução Francesa, Michelet (2010, p. 199) afirmou que as suas personagens "não são de maneira nenhuma ideias, sistemas, sombras poéticas; cada uma delas foi trabalhada, penetrada, até encontrar o homem íntimo”. Em seguida, ele arrematou:

Nenhum desses grandes atores da revolução me deixou frio. Não vivi com eles, não acompanhei cada um deles, no fundo de seu pensamento, em suas transformações, como companheiro fiel? Com o tempo, eu era um dos seus, um familiar desse estranho mundo. Eu me dera olhos para ver entre essas sombras, e creio que elas me conheciam, viam-me só, com elas nessas galerias, nesses vastos arquivos raramente visitados... A poeira do tempo permanece. É bom respirá-la, ir e vir através desses papéis, desses dossiês, desses registros. Eles não estão mudos, e tudo isso não está morto quanto parece. Eu jamais os tocava sem que certa coisa deles saísse, despertasse (MICHELET, 2010, p. 100).

Pinheiro Chagas, depois de desfilar suas metáforas anatômicas, reafirma seus pressupostos aproximando-se da metodologia adotada por Michelet:

O estudo consciencioso da época é indispensável tanto ao historiador, como ao romancista, mas o primeiro cumpriu a sua missão, expondo claramente os resultados que colheu, e compreendendo e fazendo compreender o caráter genérico de uma determinada era. O segundo, além disto, vê-se obrigado a analisar a influência da organização social do passado nas paixões, nos costumes, na vida doméstica de cada um dos indivíduos dessa geração, que o historiador estudou em globo, e que o romancista tem de estudar nas suas mais insignificantes frações (CHAGAS, 1866, p. 59).

Depreende-se desse fragmento que a escala de observação e o enfoque narrativo interferem na maneira como os objetos históricos são recepcionados pelo leitor. A mesma preocupação pode ser encontrada no romance O juramento da Duquesa, quando Chagas (1902b[1983], p. 100) abraçou o encargo de celebrar não "os grandes feitos das campanhas da Restauração, mas “os enredos da corte, as calúnias, as traições que se 
desenrolavam no reverso desse quadro brilhante das épicas pelejas e de sobre-humanas façanhas". Na sequência, o autor não deixa de insistir que

[...] também isto é história, também isto é mister que se conte, e não se colhe menos proveito da narrativa das fraquezas e dos defeitos dos nossos antepassados, que são para nós amargas lições, do que da narrativa das suas virtudes e das glórias, que são para nós glorioso incitamento (CHAGAS, 1902b, p. 100).

Em A máscara vermelha (1902a[1873], p. 227), a mesma preocupação com os "excluídos" da história foi manifestada durante uma comparação entre discursos históricos e trágicos:

\begin{abstract}
A história não nos dá pormenores acerca da execução dos plebeus, limita-se a dizer-nos unicamente como padeceram e morreram os nobres. Assim como a musa trágica se envergonhava de fazer figurar no teatro os infortúnios burgueses, e não calçava o coturno clássico senão para interessar os espectadores pelas desgraças dos grandes, assim também a história não se dignava ocupar-se da vida e gestos, e muito menos ainda da morte mais ou menos dolorosa dessa plebe vil que tumultuava na sombra.
\end{abstract}

Incomodava a Pinheiro Chagas uma história voltada para as grandes personagens e que olvidava aquelas que circulavam às margens. Nas instâncias liminares de O naufrágio de Vicente Sodré (CHAGAS, 1894, I), o autor admitiu a importância da "forma romântica" para apresentar a "vida íntima" dos antepassados ilustres dos portugueses, mostrando os bastidores "daquelas tragédias épicas, que constituem as nossas grandes e gloriosas guerras". Se a "velha fórmula do romance histórico" teria sido vítima de desprestígio por parte do público leitor, o autor assegurou que a "curiosidade de ver os personagens históricos apeados do seu pedestal, e movendo-se nas peripécias da vida comum, é cada vez mais intensa" (pp. I-II). Ele recorre a um conjunto de medidas para solucionar o dilema: "não procurar o drama fora da realidade, não inventar episódios, nem fantasiar personagens, procurar simplesmente ver as cenas tais como a história as descreve, compreender os personagens como eles se revelam nos seus atos" (CHAGAS, 1894, p. II). A "fotografia" desenhada no nosso espírito pelo estudo deveria ser estampada no "papel” para, em seguida, alcançar o público leitor.

A ideia seria fazer "reviverem" as épocas históricas sem prejudicar o interesse dramático das narrativas. Entretanto, o escritor deveria se ater à fidedignidade dos autores consultados: 
Há muitos em cuja narrativa se pode crer, mas em todo o caso, por maior que seja a boa-fé do narrador, há sempre a descontar os erros que ele comete involuntariamente, graças ao prisma que a sua paixão política lhe põe diante dos olhos, sem que ele dê por isso (CHAGAS, 1894, p. III).

Chagas, em seguida, afirma que recorreu às Lendas da Índia, de Gaspar Correia, e evitou a fantasia, limitando-se a empregar as personagens históricas e a colocar-lhes nos lábios "as palavras que estavam no seu pensamento, mas que eles talvez não poderiam exprimir com a nitidez com que podemos formulá-las agora" (CHAGAS, 1894, p. IV). Para ele, a história "tem duas faces, e nenhuma se deve ocultar" (p. V).

Quando analisa os trabalhos dos historiadores João de Barros e Diogo do Couto, Pinheiro Chagas (1867, p. 211) distingue a eloquência do primeiro, responsável por uma "epopeia em prosa dos feitos portugueses", e o "lápis severo" do segundo, que abriu mão do "pincel maravilhoso do colorista” para desenhar com precisão os episódios históricos, captando as luzes sem negligenciar as sombras. Se Barros amplifica os atributos heroicos, Couto evidencia seus traços humanos sem, com isso, repelir seus leitores. O "historiador soldado", à maneira de Camões, teria empunhado a pena e a espada, ou seja, ele foi capaz de associar experiência e erudição, não se limitando aos ambientes da Corte (p. 211). Os juízos de Chagas partem do pressuposto de que tópicas como "pena e espada" seriam descrições individuais ou biográficas (no sentido moderno do termo), e não elementos típicos ou convencionais mobilizados na composição de personae, de personagens/pessoas notáveis ora pela erudição cortesã, ora pela experiência bélica. Por ter conciliado a vida parlamentar e a escrita literária/histórica, talvez o romancista tenha encontrado em Couto um modelo de historiador compatível com sua própria trajetória.

O que perdura no século XIX não é o caráter exemplar de uma história voltada para a instrução dos pósteros, mas os lugares-comuns que subsidiaram o gênero historiográfico. Isso acontece porque a eficácia das tópicas perdurou para além do desmantelamento da Instituição Retórica, ou seja, muitos críticos literários, literatos e historiadores do século XIX apreenderam o artifício como elemento empírico, como descrição fidedigna proveniente da observação testemunhal. A análise de alguns fragmentos de Pinheiro Chagas poderá nos ajudar a averiguar de que maneira esse romancista retomou algumas tópicas presentes nas fontes que consultou. 
Na novela histórica $A$ passagem do cabo Bojador, publicada em 1869 e republicada em 1894, Chagas retratou, no primeiro capítulo, um diálogo entre o infante D. Henrique e Gil Eanes. Este referia os perigos que encontrariam os marinheiros ao ultrapassar o cabo Bojador; já aquele alegava que, com intenções íntegras, poder-se-ia passar ileso até mesmo pelo inferno:

Para visitar as regiões sombrias, as mortais defesas, colheu Eneias no bosque misterioso o ramo de ouro protetor. Mas onde há ramo de ouro conhecido das Sibilas que seja melhor talismã do que a própria cruz de Cristo? Empunhai a cruz, Gil Eanes, tende fé, e vereis dissiparem-se os vãos prestígios com que o demônio vos aterra (CHAGAS, 1894, p. 131).

Durante a tão aguardada viagem rumo ao cabo, um "velho marinheiro de voz autorizada e grave" começou a espalhar estórias sobre águas "negras como breu" que "referviam e erguiam-se como montanhas" e marinheiros que, na "flor da mocidade", desistiram da viagem quando avistaram o Bojador e voltaram para Portugal com "cabelos brancos" (CHAGAS, 1894, p. 136).

O mesmo marinheiro, chamado Lourenço Dias, narrou outra anedota, dessa vez protagonizada por São Brandão, que teria encontrado o paraíso terrestre depois de cruzar o mar "semeado de ilhas que pertencem a Satanás" e nas quais "as almas sofrem as penas do inferno" (CHAGAS, 1894, p. 137). Depois de ultrapassá-las e ouvir "gemido e prantos", além de "patadas de cavalos de fogo" montados "por infelizes que soltavam gritos horríveis", São Brandão teria encontrado "uma ilha resplandecente”, na qual cantavam pássaros de ouro com "asas de prata” e peito "de púrpura e de açafrão" (p. 137). O romancista imitou uma passagem de Gomes Eanes de Zurara (1973, p. 50), presente na Crónica de Guiné, ao sugerir que, depois do Bojador, "a terra é mais baixa que o mar, que o sol queima as praias escalvadas, e que as correntes impetuosas arrastam com irresistível força os navios para terríveis paragens, onde a morte é certa" (CHAGAS, 1894, p. 128). Entretanto, quando finalmente ultrapassaram o cabo, a experiência não correspondia às expectativas. Segundo Chagas, essa teria sido a "maior façanha da história moderna" (p. 128).

Quando surgiu oportunidade, Pinheiro Chagas esclareceu aspectos controversos das crônicas consultadas, como é o caso do locus horrendus que empregou para representar as proximidades do temível cabo: o vento da madrugada emitia "gemidos fúnebres" que se assemelhavam "aos queixumes das almas penadas"; ouvia-se ao longe "um som rouco e mal 
distinto" do "mar quebrando com fúria nos rochedos"; o mar "tingira-se de vermelho escuro; parecia ter perdido a liquidez, e na superfície baça das vagas ficara por largo espaço traçada a esteira da barca aventurosa" (CHAGAS, 1894, p. 138). Na sequência, ele afirmou que a causa do fenômeno em questão

[...] é conhecida hoje de todos os navegantes; para o sul do cabo de Não, a muita areia soprada pelo vento do deserto avermelha as águas do Oceano e torna-as espessas; mas os marinheiros de Gil Eanes julgavam que era um prenúncio da aproximação do mar Tenebroso (CHAGAS, 1894, p. 138).

A novela, no caso, não se limita à reprodução da fonte, pois presta ao leitor esclarecimentos que os antigos cronistas não poderiam formular. A ideia de fazer "reviverem" os agentes históricos não parte de uma concepção ingênua de imparcialidade ou objetividade, já que cabe ao romancista a produção da verossimilhança narrativa.

As palavras do "velho marinheiro" ocuparam na intriga uma posição similar ao discurso proferido pelo Velho do Restelo na epopeia lusíada: as palavras de Lourenço Dias reuniam lendas que outrora impediram os nautas de ultrapassarem o Bojador e costearem as terras africanas. $\mathrm{O}$ cabo funcionaria como um nec plus ultra, como um limite a ser evitado, assim como o cabo das Tormentas algumas décadas depois. Pinheiro Chagas buscou reabilitar a memória de Gil Eanes e D. Henrique, atribuindo-lhes o prestígio merecido e integrando-os à história nacional. Há, portanto, um caráter instrutivo, uma tentativa de demonstrar que o dissipar das superstições proporcionou aos portugueses a possibilidade de prosperar. No entanto, ao favorecer a presença dos jesuítas, a má administração dos monarcas e o envolvimento em guerras alheias, a Dinastia de Avis teria impedido a continuidade dessa prosperidade (GANDRA, 2012, p. 79).

Figuras elocutivas também foram admitidas nos romances de Chagas e encaradas como elementos de uma narrativa testemunhal. Em O terremoto de Lisboa (1874), por exemplo, o romancista descreveu com minúcias os efeitos do sismo e as ondas dele resultantes:

O rio fugia como horrorizado das margens, repelido para longe pela convulsão da terra, as aguas da maré, encontrando-se com as que se retraíam das praias, lutavam em furioso embate, encastelavam-se em montanhas gigantes, e, arrojando-se de novo sobre as praias, desabavam na cidade e submergiam os cais, entravam por Lisboa dentro até distâncias enormes, chegando às portas de Santo Antão, e de novo se retiravam e voltavam, mais aglomeradas, mais furiosas, mais espumantes, alagando as ruínas, quebrando nas paredes dos edifícios, trazendo consigo, enrolada nas ondas, a morte debaixo de um novo 
aspecto. Era a formidável confusão da natureza, era a medonha luta entre todos os elementos, era o horror debaixo de todas as suas formas, a convulsão da terra, a tempestade das aguas, a lúgubre escuridão, os boqueirões do inferno mostrando as fauces hediondas, o incêndio que principiava, a imagem tremenda do chãos, o ideal sinistro do Báratro (CHAGAS, 1874, pp. 176-177).

As metáforas topográficas mobilizadas nesta descrição possivelmente foram inspiradas em uma carta de 1756 , na qual Bento Morganti afirmou que, com os "impulsos da terra", o mar "se retirou", deixando "nas suas margens ver o fundo às suas águas nunca de antes visto" (MORGANTI, 1756, p. 114). As águas encapelaram-se "em altíssimos montes" e invadiram a capital portuguesa com ímpeto, como se pretendesse submergi-la "estendendo os seus limites" (p. 114).

Elementos retóricos provenientes dos antigos gêneros letrados perseveraram no século XIX, muitas vezes encarados como descrição fidedigna de sentimentos, paixões ou, como dizia Pinheiro Chagas, de elementos provenientes dos "bastidores". Na tentativa de despertar a curiosidade do leitor sem entendia-lo, Chagas atribuiu vida aos mortos e, simultaneamente, colocou em circulação tópicas que naturalizou por ter sido vítima dos seus efeitos, ou seja, ele recepcionou o artifício como manifestação natural da sensibilidade das personagens históricas. Com isso, não legou aos pósteros exemplos edificantes, mas deixou ao público coevo lições nacionais, almejando atingir os antigos pressupostos da retórica: instruir, mover e deleitar. Como dizia o português Francisco Freire de Carvalho (1840, p. 82), autor de Lições elementares de poética nacional,

Descrição é a pedra de toque da imaginação do Poeta, e a que faz diferençar facilmente o engenho original do talento meramente copista. Na verdade quando um escritor medíocre empreende descrever a Natureza, figurasse-lhe, que todos quantos o precederam, tem esgotado a matéria; nada descobre novo e particular no objeto, que intenta pintar; a imagem, que dele forma, é vaga e mal circunscrita: consequentemente as suas expressões são fracas e gerais. Pelo contrário o verdadeiro Poeta põe diante dos olhos de seus leitores o objeto que descreve, sem lhe escapar nenhuma de suas feições mais notáveis; pinta-o com as suas cores naturais; dá-lhe uma existência, uma vida real; coloca enfim esse objeto debaixo de um ponto de vista tão adaptado e frisante, que o pintor pode em um quadro facilmente copiá-lo.

Não deixar escapar nenhuma das feições mais notáveis do objeto; pintá-lo com "cores naturais" (para não dizer nacionais); dar-lhe existência, galvanizá-lo e ajustar seus atributos ao "ponto de vista" do leitor. Todas 
essas medidas foram preceituadas por Pinheiro Chagas em seus ensaios críticos e adotadas em seus romances, contos e novelas históricas, pois havia um decoro a ser seguido, ou seja, uma necessidade de ajustar a matéria ao gênero literário e o gênero ao "curioso" público consumidor de literatura.

A literatura reuniu, em seu bojo, elementos outrora distribuídos entre os mais variados gêneros letrados. Por meio dela, alguns vestígios retóricos resistiram à força destrutiva do tempo. Não é de se estranhar, portanto, que a História, com agá maiúsculo, definiu seus pressupostos medindo-se com a literatura (e vice-versa). Para Pinheiro Chagas, a melhor maneira de rivalizar com o historiador seria recorrendo à história, mas para fazer repercutir os silêncios de outrora. Para tanto, seria oportuno recorrer a uma unidade dramática capaz de atrair a atenção do leitor pouco afeito às crônicas desprovidas de acabamento literário ou às ficções destituídas de conteúdo histórico. Por outras palavras, ele colocou a antiga tópica historiográfica sine ira et studio a serviço da literatura para promover a nacionalidade portuguesa na condição de bardo da história.

Com seu habitual tom satírico, Eça de Queiroz afirmou que o "brigadeiro Chagas" não passava de um "velho personagem do século XVII, com mais de 145 anos de idade, pintado por fora duma cor natural de vida moderna, mas ressequido e pulverulento por dentro" (GANDRA, 2007, p. 94). De acordo com o autor de O primo Basílio, seu modo de pensar e falar, próprio da "sociedade portuguesa do tempo da senhora D. Maria I", revelaria um patriotismo antiquado, retrógrado (QUEIROZ apud GANDRA, 2007, p. 94). A perseverança de antigas tópicas possivelmente não motivaria uma crítica tão mordaz, mas Eça de Queiroz foi incisivo ao afirmar que Pinheiro Chagas habitava um "mundo fictício, convencional, artificial" (p. 99), diferentemente do mundo "mais vivo e real" ao qual pertencia. Diante do hiato que os separava, Queiroz confrontou seu antagonista ironizando a (suposta) maior virtude dele: conhecedor exímio da história, Chagas teria superado a condição do anacronismo para viver no tempo dos cronistas que apreciava e confabular com as extintas personagens que empregou em seus romances.

\section{PALAVRAS FINAIS}

Pinheiro Chagas recorreu à história para retirar dela lições nacionais que pudessem mover seus leitores, afrontar seus desafetos literários e endireitar a trajetória de Portugal. Mas de onde provém sua utilidade? 
Oliveira Martins (1972), contemporâneo (e desafeto) de Chagas, principia sua "Advertência" à História de Portugal, de 1879, com uma epígrafe proveniente da Coronica do Condestabre, que define a historia magistra vitae ao afirmar que é tarefa do historiador fazer memória dos erros, para não se repetirem, e dos grandes feitos, para que sirvam de exemplo. Em seguida, ele afirma, possivelmente inspirado em Michelet, que "A história é sobretudo uma lição moral" (MARTINS, 1972, p. 8). No entanto, sua afirmativa não busca salvaguardar a tópica ciceroniana, mas conceber a História como um gênero novo amparado em pressupostos científicos. Esse gênero passa a contemplar não somente os discursos morais, comuns à historiografia do século XVII, como também as doutrinas do século XVIII, com seus "sistemas gerais quiméricos", e os procedimentos adotados pelos historiadores de sua época, que se restringiam aos "aspectos exteriores" da História. Sua proposta não se resume à associação dessas três vertentes, pois detém-se, ainda, no sistema das instituições e no sistema das ideias coletivas, que "são para a sociedade como os órgãos e os sentimentos são para o indivíduo" (p. 8). À analogia fisiológica soma-se uma metáfora proveniente da dramaturgia, pois sua História atenta-se para os costumes e caracteres, para a "pintura animada dos lugares e acessórios que formam o cenário do teatro histórico" (p. 8). O historiador, ao voltar-se para o grande "teatro do mundo", faria "viver os seus homens, e representar de um modo real a cena em que se agiram" (p. 10). Oliveira Martins cogitou a possibilidade de recorrer a um estilo capaz de produzir a "animação própria das coisas vivas" e, assim como Pinheiro Chagas, valorizou sobretudo os objetos históricos que mereciam reprovação: "Nos vícios e nas virtudes, nos erros e nos acertos, na perversidade e na nobreza dos indivíduos que foram há um meio de prevenir e encaminhar a direção dos atos futuros. A história é, nesse sentido, a grande mestra da vida" (MARTINS, 1972, p. 12).

Antes de Oliveira Martins, Alexandre Herculano tinha escrito os quatro tomos de sua História de Portugal (1846-1853) com o propósito de, igualmente, torná-la útil. Na "Advertência" à terceira edição (HERCULANO, 1863), afirma-se que o trabalho deveria ser usufruído pelo futuro rei de Portugal. O historiador assim procedeu por reconhecer que “o conhecimento da vida anterior de uma nação" seria de grande auxílio, por temperar "as generosas, mas nem sempre esclarecidas e prudentes aspirações do progresso pela experiência e sabedoria de um passado que também já foi progresso" (HERCULANO, 1846, p. 4). De acordo com 
Arthur Assis (2019, pp. 304-305), ao destinar a sua História à "educação do futuro monarca" e expor "virtudes e vícios manifestos na ação dos primeiros reis portugueses", a obra em questão se afinaria a outro gênero por apresentar "reminiscências da antiga tradição pragmática dos espelhos dos príncipes". Herculano recorreu a um "patriotismo" divorciado de uma "retórica triunfalista", ou seja, a busca criteriosa pela verdade seria uma maneira de prestar grande serviço ao seu país. Nem por isso, deixou de detectar na história vestígios da Providência, que atuava em conformidade com as invariáveis leis de ordem moral que regiam o universo.

A atmosfera romântica conferiu subsídio para que o historicismo expandisse e se desenvolvesse, mas a historiografia também forneceu aos literatos critérios legitimadores. De um lado e de outro, declarou-se guerra à razão absoluta e ao universalismo ilustrado, valorizando-se as singularidades regionais e/ou nacionais, mas também o potencial promissor da estética em detrimento da retórica. Nas primeiras décadas do Oitocentos, após a Revolução Liberal, historiadores e literatos portugueses buscaram "refundar a nação" e recuperar a índole da "alma nacional" valorizando o pitoresco, o popular, as tradições (CATROGA, 1994). Podemos observar um cenário análogo no Brasil poucas décadas depois, quando poetas como Gonçalves de Magalhães e Gonçalves Dias negaram a importância da instituição retórica e heroicizaram a figura do índio. Os historiadores do IHGB, por sua vez, se entregavam à tarefa de recompor o processo de gênese do Brasil, movidos pelo projeto nacionalista de D. Pedro II e pela vontade de dotar a jovem nação de autonomia cultural. Vale ressaltar que Pinheiro Chagas não apenas conhecia esse projeto brasileiro de constituição de um passado nacional como também chegou a censurar os romances indianistas de José de Alencar, dizendo que a antiga colônia portuguesa ainda não dispunha de uma literatura nacional.

A perseverança de topoi historiográficos atesta a longa duração da historia magistra vitae e relativiza a ideia de que os românticos teriam rompido definitivamente com a retórica para expressar originalmente as circunstâncias do seu presente e manifestar a autenticidade dos seus afetos. Na "Advertência" à primeira edição da História de Portugal, Alexandre Herculano (1846, p. 1) afirmou que os prólogos são destinados "a captar a benevolência do púbico", mas, numa obra histórica, "nem o autor deve pedi-la, nem o leitor concedê-la": averiguar "qual foi a existência das gerações que passaram, eis o mister da história. O seu fim é a verdade". Note-se que o historiador efetuou a captatio benevolentiae ao negá-la, 
reforçando seu compromisso com a objetividade. Se, por um lado, literatos e historiadores do Oitocentos alegavam a ausência do artifício retórico para transparecer naturalidade, por outro eles diziam que a história de matriz ciceroniana estava superada, ainda que suas tópicas perseverassem travestida de "patriotismo", "nacionalismo", “originalidade”, "gênero novo" etc. Convém assimilar os equívocos pregressos que repercutiram sobejamente em meio à crítica literária e admitir que o artifício não revela expressivamente a subjetividade do artífice, mas integra objetivamente os pressupostos datados de sua arte. É verossímil considerar, portanto, que vestígios da historiografia antiga e moderna continuam circulando ainda hoje, o que confirma dois movimentos simultâneos, inaugurados no século XIX: a perseverança de aspectos epistêmicos, normativos e pedagógicos outrora reunidos sob o rótulo historia magistra vitae e a descontinuidade - transformação, estreitamento, (in)definição - do topos, tão perceptível quanto maior for nosso comprometimento em historicizar o passado.

\section{REFERÊNCIAS}

ANÔNIMO. Retórica a Herênio. São Paulo: Hedra, 2005.

ARAÚJO, Valdei Lopes de. Sobre a permanência da expressão historia magistra vitae no século XIX brasileiro. In: NICOLAZZI, Fernando (Org.). Aprender com a história? O passado e o futuro de uma questão. Rio de Janeiro: FGV, 2011, p. 131-147.

ASSIS, Arthur Alfaix. Alexandre Herculano entre a imparcialidade e a parcialidade. História da Historiografia, Ouro Preto, v. 13, n. 32, 2020, pp. 289-329.

BOUTON, Christopher. Learning from History - The Transformations of the Topos Historia Magistra Vitae in Modernity. Journal of the Philosophy of History, 2018, pp. 1-33.

CARVALHO, Francisco Freire de. Lições elementares de poética nacional, seguidas de um breve ensaio sobre a crítica literária. Lisboa: Tipografia Rollandiana, 1840.

CATROGA, Fernando. Romantismo, literatura e história. In: TORGAL, Luís Reis; ROQUE, João Lourenço (Coords.). História de Portugal. O Liberalismo (1807-189o). Vol. 5. Lisboa: Círculo de Leitores,1994.

CEZAR, Temístocles. Historia magistra vitae. Ensaio sobre a (in)definição do topos nos projetos de escrita da história do Brasil no século XIX. In: PROTÁSIO, Daniel Estudante (Org.). Historiografia, cultura e política na época do Visconde de Santarém. Lisboa: Editora do Centro de História da Universidade de Lisboa, 2019, pp. 21-44.

CHAGAS, Pinheiro. Ensaios críticos. Porto: Casa de Viúva Moré, 1866. 
CHAGAS, Pinheiro. Novos ensaios críticos. Porto: Casa de Viúva Moré, 1867.

CHAGAS, Pinheiro. O terramoto de Lisboa: romance original. Lisboa: Livraria Editora de Mattos Moreira, 1874.

CHAGAS, Pinheiro. O naufrágio de Vicente Sodré. Lisboa: Livraria de Antonio Maria Pereira, 1894.

CHAGAS, Pinheiro. A máscara vermelha. Romance Histórico Original. 3. ed. Lisboa: Empreza da Historia de Portugal, 1902a.

CHAGAS, Pinheiro. O juramento da Duquesa. Romance Histórico Original. 3. ed. Lisboa: Empreza da Historia de Portugal, 1902b.

CHARTIER, Roger. A verdade entre a ficção e a história. In: SALOMON, Marlon (Org.). História, verdade e tempo. Chapecó: Argos, 2011, pp. 137-146.

FELIPE, Cleber Vinicius do Amaral. Itinerários da conquista: uma travessia por mares de papel e tinta (Portugal, séculos XVI, XVII e XVIII). Tese (Doutorado em Filosofia) - Instituto de Filosofia e Ciências Humanas, Universidade Estadual de Campinas (Unicamp), 2015.

GANDRA, Jane Adriane. A (de)formação da imagem: Pinheiro Chagas refletido pelo monóculo de Eça de Queiroz. 2007. Dissertação (Mestrado em Letras) - Faculdade de Filosofia, Letras e Ciências Humanas, Universidade de São Paulo (USP), São Paulo, 2007 .

GANDRA, Jane Adriane. Pinheiro Chagas, um escritor olvidado. 2012. Tese (Doutorado em Letras) - Faculdade de Filosofia, Letras e Ciências Humanas, Universidade de São Paulo (USP), São Paulo, 2012.

GINZBURG, Carlo. O fio e os rastros: verdadeiro, falso, fictício. Trad. Rosa Freire d'Aguiar e Eduardo Brandão. São Paulo: Companhia das Letras, 2007.

HANSEN, João Adolfo. Barroco, Neobarroco e outras ruínas. Floema Especial (UESB), ano II, n. 2, 2006, pp. 10-67.

HARTOG, François. Evidência da história: o que os historiadores veem. Trad. Guilherme João de Freitas Teixeira. Belo Horizonte: Autêntica, 2011.

HERCUlANO, Alexandre. História de Portugal. Tomo Primeiro. Lisboa: Casa da Viúva Bertrand e Filhos, 1846.

HERCULANO, Alexandre. História de Portugal - desde o começo da monarquia até o fim do reinado de Afonso III. 3. ed. Lisboa: Casa da Viúva Bertrand e Filhos, 1863.

HORÁCIO. A arte poética. Trad. e estudo de Dante Tringali. São Paulo: Musa, 1994. 
KANTOROWICZ, Ernst Hartwig. Os dois corpos do Rei: um estudo sobre teologia política medieval. Trad. Cid Knipel Moreira São Paulo: Companhia das Letras, 1998.

KOSELLECK, Reinhart. Futuro passado: contribuição à semântica dos tempos históricos. Trad. Wilma Patrícia Maas e Carlos Almeida Pereira. Revisão de César Benjamin. Rio de Janeiro: Contraponto/Ed. PUC-Rio, 2006.

MÁRQUEZ, Jaime Valenzuela. Relaciones jesuitas del terremoto de 1730: Santiago, Valparaíso y Concepción. Cuadernos de Historia, n. 37, 2012, pp. 195-224.

MARTINS, Oliveira. Advertência. In: História de Portugal. Lisboa: Guimarães Editores, 1972.

MEGIANI, Ana Paula Torres; CERQUEIRA, André Sekkel. Como se escrevia a história no século XVII: o uso dos tratados espanhóis, italianos e franceses pelos historiadores portugueses. Revista de História, São Paulo, n. 179, 2020, pp. 1-32.

MICHELET, Jules. Prefácio de 1868. Trad. Lilia Moritz Schwarcz. In: MALERBA, Jurandir (Org.). Lições de história: o caminho da ciência no longo século XIX. Rio de Janeiro: Editora FGV, 2010.

MORGANTI, Bento. Carta de hum amigo para outro, em que se dá succinta noticia dos effeitos do terremoto, succedido em o Primeiro de Novembro de 1755. Com alguns principios fisicos para se conhecer a origem, e causa natural de similhantes phenómenos terrestres. Lisboa, Offic. Domingos Rodrigues, 1756.

OLIVEIRA, Maria da Glória de. Biografia e historia magistra vitae: sobre a exemplaridade das vidas ilustres no Brasil oitocentista. Anos 9o, Porto Alegre, v. 22, n. 42, 2015, pp. 273-294.

SILVA, Manoel Telles da. História da Academia Real da História Portugueza. Lisboa: Officina de Joseph Antonio Sylva, 1727.

SINKEVISQUE, Eduardo. Usos da écfrase no gênero histórico seiscentista. História da Historiografia, n. 12, 2013, pp. 45-62.

WHITE, Hayden. Trópicos do discurso: ensaios sobre a crítica da cultura. São Paulo: Edusp, 2001, pp. 137-151.

ZURARA, Gomes Eanes de. Crónica de Guiné. 2. ed. Introdução, novas anotações e glossário de José de Bragança. Barcelos: Livraria Civilização Editora, 1973.

ZURARA, Gomes Eanes de. Crônica da Tomada de Ceuta. Lisboa: Publicações Europa-América, 1992.

Recebido: 2/12/2021

Aceito: 22/6/2021

Publicado: 22/12/2021 